\title{
Nursing Offices
}

\section{Evelin Capellari Cárnio}

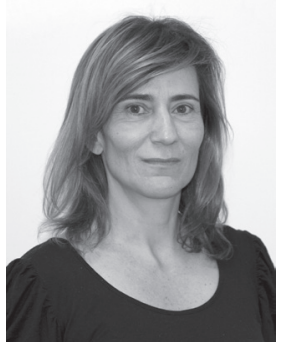

We have recently observed a great expansion in nurses' activity area. This process is characterized by a redefinition of the limits of professional performance, accompanied by greater autonomy in professional practice. One example of this new perspective is the opening of nursing offices. An estimated number of more than 700 are functioning in Brazil nowadays.

The Ministry of Health has stimulated health practices that go beyond the dichotomous knowledge that is only focused on the physical-pathological process. At these offices, professionals need to be capable of delivering multidisciplinary and humanized care, based on the health concept. They can also advise their patients about the need for good health practices and about disease prevention and complementary treatment forms.

Some doubts remain, however, about the legal responsibilities of nurses in consultation services, or on the occasion of medical or nursing consultations. In countries like the United Kingdom, United States and Canada, these responsibilities have been better established and nurses can treat a wide range of illnesses. Examples include animal bites, conjunctivitis, eczema, cystitis, impetigo, oral cavity ulcers and others. They are also allowed to offer a wide range of special services, such as dressings, child vaccination, health advice to parents of small children and family planning orientations. They also deliver routine care and request complementary tests for a series of chronic problems, such as asthma, diabetes and hypertension. Moreover, these professionals submit patients who were victims of strokes or cerebrovascular accidents to an annual assessment.

As, in Brazil, nurses' responsibilities in nursing offices have not been fully defined yet, during Ordinary Plenary Meeting No. 424 of the Federal Nursing Council, a Work Group was created to discuss their regulation. This work group is responsible for assessing nurses' activities in these offices, for quantifying them and developing research aimed at establishing activity schedules, as determined in the law that regulates professional practice (Law 7.498/86) $)^{(1)}$.

To contribute to this process, nursing researchers need to contribute to research in the area, presenting their findings about this new activity and the perspectives for the expansion of nursing professionals' activities in Brazil. 


\section{References}

1. Conselho Federal de Enfermagem (Cofen). Lei no 7.498/86, de 25 de junho de 1986. Dispõe sobre a regulamentação do exercício da Enfermagem e dá outras providências [Internet]; [acesso 20 jun 2013]. Disponível em: http://novo. portalcofen.gov.br/lei-n-749886-de-25-de-junho-de-1986_4161.html

Evelin Capellari Cárnio is Associate Editor of the Latin American Journal of Nursing and Associate Professor of the Escola de Enfermagem de Ribeirão Preto, Universidade de São Paulo, WHO Collaborating Centre for Nursing Research Development, Brazil, e-mail carnioec@eerp.usp.br. 